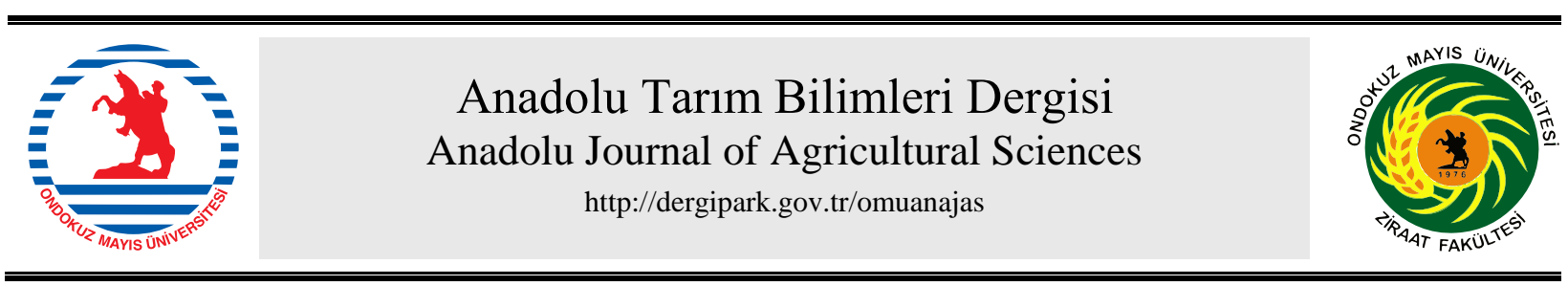

Araştırma/Research

Anadolu Tarım Bilim. Derg./Anadolu J Agr Sci, 36 (2021) ISSN: 1308-8750 (Print) 1308-8769 (Online) doi: 10.7161/omuanajas.839239

\title{
Determination of tail fat fatty acids profile in some local sheep breeds of Black Sea Region
}

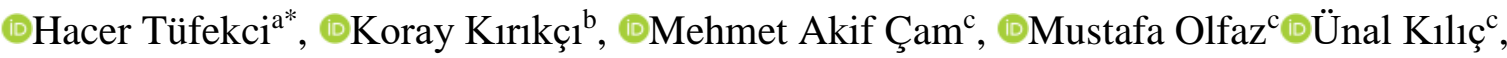 \\ Levent Mercan ${ }^{\mathrm{d}}$
}

\author{
${ }^{a}$ Department of Animal Science, Faculty of Agriculture, Yozgat Bozok University, 66100 Yozgat, Turkey; \\ ${ }^{b}$ Department of Animal Science, Faculty of Agriculture, Kırşehir Ahi Evran University, 40000, Kirşehir, Turkey \\ ${ }^{c}$ Department of Animal Science, Faculty of Agriculture, Ondokuz Mayls University, 55200, Samsun, Turkey \\ ${ }^{d}$ Department of Agricultural Biotechnology, Faculty of Agriculture, Ondokuz Mayls University, 55200, Samsun, Turkey
}

*Corresponding author: hacer.tufekci@bozok.edu.tr

Geliș/Received 11/12/2020 Kabul/Accepted 28/04/2021

\begin{abstract}
In the study, the contents of tail fat fatty acid composition of 6-month-old male lambs in the breeds of Artl1, Çepni, Karayaka and Of grown in the Black Sea Region were examined. The content of saturated fatty acids in tail fat for the breeds of Artl1, Çepni, Karayaka and Of were respectively; 52.08\%, $51.66 \%, 42.67 \%, 52.92 \%$ while the monounsaturated fatty acid contents were $33.25 \%$, 33.12\%, $33.07 \%, 32.34 \%$ respectively. The content of polyunsaturated fatty acids was determined as $0.76 \%$, $1.20 \%, 0.64 \%$ and $0.87 \%$, respectively. The presence of fatty acids desired for health was determined as 46.94\% in Artl1, 51.03\% in Çepni, 51.51\% in Karayaka and $49.51 \%$ in the breeds of Of. In terms of polyunsaturated fatty acids in the composition of fatty acids, the highest rate was found in the Çepni breeds and the lowest in the Karayaka breeds. It has been determined that the fatty acid content has significant differences between breeds.
\end{abstract}

Karadeniz Bölgesi bazı yerel koyun 1rklarında kuyruk yağı yağ asitleri profilinin belirlenmesi

\section{ÖZET}

Çalışmada Karadeniz Bölgesinde yetiştirilmekte olan Artlı, Çepni, Karayaka ve Of ırkında 6 aylık yaştaki erkek kuzuların kuyruk yağı yağ asitleri kompozisyonları ve yağ asidi miktarları incelenmiştir. Artlı, Çepni, Karayaka ve Of ırkı için sırasıyla kuyruk yağında doymuş yağ asitleri içeriği; \%52.08, $\% 51.66, \% 42.67, \% 52.92$ olarak, tekli doymamış yă̆ asitleri içeriği aynı sırayla \%33.25, \%33.12, $\% 33.07$ ve \%32.34 olarak bulunmuştur. Çoklu doymamış yağ asitleri içerikleri ise aynı sırayla \%0.76, $\% 1.20, \% 0.64$ ve \%0.87 olarak bulunmuştur. Sağlık açısından olması istenen yağ asitleri Artlı 1rk1 kuzularda \%46.94, Çepni ırkı kuzularda \%51.03, Karayaka ırkı kuzularda \%51.51 ve Of ırkı kuzularda \%49.51 olarak belirlenmiştir. Çoklu doymamış yağ asitleri bakımından en yüksek oran Çepni ırkında ve en düşük oran ise Karayaka ırkında tespit edilmiștir. Yağ asitleri içeriğinin ırklar arasında önemli farklılıklar taşıdığ 1 saptanmıştır.
Keywords: Artli sheep Çepni sheep Of sheep Tail fat fatty acids Fattening

Anahtar Sözcükler: Artlı koyunu Çepni koyunu Of koyunu Kuyruk yağı yağ asitleri Besi

(C) OMU ANAJAS 2021 


\section{Introduction}

As in many countries, the economic importance of products derived from sheep and sheep in Turkey, and its share in meeting the nutritional needs of the animal population is quite large. Changes in the socio-economic structure, cultural developments and population growth have increased the interest of Turkish people in animal protein and especially meat consumption. The climate conditions, the landscape, and pastures being more conducive to the sheep breeding in Turkey, as well as intensive livestock farming can not be made, industry is still in the stage of development, and mutton demand, increases the importance of the choice of sheep (Tekin and Akçapınar, 1994; Akçapınar, 2000; Kaymakçı 2006; Öztürk and Odabaşığlu, 2011; Aksoy and Yavuz, 2012).

As a result of the climate and environmental conditions of different settlements, human migrations, changes in the priorities for benefiting from animals and genetic improvement studies, nearly 2000 sheep breeds have occurred in the world. The most important morphological difference between these sheep breeds with different morphological and physiological characteristics is their tail structure (Akçapınar and Özbeyaz, 1999; Akçapınar, 2000). Fat in the tail serves as an energy source when nutrient intake is not sufficient (Kashan et al., 2005; Teke et al., 2018). One of the products obtained from the slaughter of cattle and fat-tailed sheep is tallow fat and tail fat. Sheep tail fat is the main source of aroma especially in the production of kebabs and some dishes. Animal fats are the second most important source of fat raw materials produced in our country (Ünal and Karakaya, 2017).

Animal fats can be used for cooking, as well as being used as an ingredient in various foods and especially as an essential component of meat products, in addition, animal fats have a particularly significant effect on the textural parameters of meat products (Forrest et al., 1975; Pehlivanoğlu et al., 2018). The increase in the use of animal fats in nutrition, which started in the 1950s, has continued exponentially and this increase continues today. Fats are the most energy-dense nutrients, with 9 calories per gram of fat. The energy contained in fats is 2.25 times or higher than resources such as starch, digestible crude fiber and cereal grains. Due to its high energy value, it is a feed substance that is widely used in the feeding of dairy and beef cattle and sheep and poultry rations, and its usage area is expanding day by day (Donna et al., 2002; Canbolat and Karabulut 2003). Vegetable and animal oils can also be used as alternative fuel. Animal fats can also be converted into biodiesel with simple reactions (Karaosmanoğlu, 2002; Üstün, 2006; Utlu, 2007; Behçet et al., 2012).

Although the saturation of body fat varies between animal species and according to breeds within the same species, ruminants store more saturated fat than non-ruminant animals (Öztürkcan et al., 1996). The most important factors affecting the fatty acid composition; genotype, feeding and breeding methods, age, sex, type of fat storage and anatomical region. The main factor determining the quality of the oil is its fatty acid composition (Lunn and Theobald, 2006). Since cultivation in intensive and extensive conditions is directly related to nutrition, tissue fatty acid composition is affected. The general view is that unsaturated fatty acids increase in animals fed on pasture, but the amounts of C16: 0 and C18: 0 fatty acids are also increasing in parallel (Wood et al., 2003; Demirel et al., 2004; Raes et al., 2004).

The fact that there are many uses of animal fats both as food and as an alternative has made it necessary to examine the physical properties of these fats. In this study, the contents of tail fat fatty acid composition of 6-monthold male lambs with genotypes Artlı, Çepni, Of and Karayaka, raised in the Black Sea Region, were investigated.

\section{Materials and Methods}

The animal material of the study consists of a total of 48 male lambs, 12 from each of the 4-4.5 months old Karayaka, Of, Artlı, Çepni genotypes in Trabzon, Artvin and Ordu region. Samples were taken for tail fat fatty acid from 10 of 12 lambs that were slaughtered. The animals were brought to Ondokuzmayis University Agricultural Application and Research Center Livestock Enterprise and placed in individual compartments of at least $1.00 \times 1.50$ $\mathrm{m}$ in size. The lambs were sheared before being taken to trial. In these compartments, fattening trials were started after 15 days of feeding and acclimation to the environment. In animal nutrition, a mixture of wheat, oats and alfalfa was used with dry grass and commercial concentrated full-fat fattening feed as much as they could eat. The trial was continued for 60 days. The nutrient needs of the lambs were determined according to NRC (2007), and clean drinking water was given to the animals freely throughout the trial.

At the end of the fattening, all of the animals belonging to each group were slaughtered in order to determine the desired characteristics of the groups. Tail fat samples were taken after the carcasses were kept at $+4{ }^{\circ} \mathrm{C}$ for 24 hours after slaughter. The samples taken to determine the fatty acid composition were kept in the deep freezer at $-18^{\circ} \mathrm{C}$ until the time of analysis, were sent to Food Institute of Marmara Research Center of Scientific and Technical Research Council of Turkey in ice molds at the time of analysis and without breaking the cold chain, and meat fatty 
acid analysis was performed through service procurement. Analysis of fatty acids was carried out according to the method of IUPAC IID19.

The GLM multivariate procedure SPSS (Ver 25) was used to determine differences in tail fat fatty acids between races. DUNCAN multiple comparison test was used to compare the means. Breeds are taken as a fixed factor.

\section{Results and Discussion}

In the experimental groups, the values related to the live weights at the beginning and end of the trial and the hot and cold carcass weight are given in Table 1 . The difference in weight per trial in the groups included in the experiment was attributed to differences in environmental conditions and genotypes up to 4 months of age. In order to compensate for this difference in the common environment, the body weight per trial was taken as coveryet in the analyzes. In this case, it was determined that the breeds had no effect on the live weights at the end of the trial. Total live weight gain in the breeds of Artlı, Çepni, Karayaka and Of was 9.45; $10.55 \mathrm{~kg} ; 11.43$ and $11.48 \mathrm{~kg}$. According to the findings obtained in the study, tail weight for the breeds of Artl, Çepni, Karayaka and Of was found to be respectively; $4.54 \mathrm{~kg} ; 0.66 \mathrm{~kg} ; 0.55 \mathrm{~kg}$, and $1.69 \mathrm{~kg}$. When we look at the ratio of tail weight and tail weight to cold carcass, it is seen that the difference between breeds is significant.

Table 1. Average values for some slaughterhouse and carcass traits in lamb breeds

\begin{tabular}{lccccc}
\hline Groups & Çepni & Karayaka & Artl & Of & P \\
\hline Starting live weights & $37.59 \pm 1.19^{\mathrm{a}}$ & $26.10 \pm 0.42^{\mathrm{c}}$ & $29.02 \pm 0.82^{\mathrm{c}}$ & $31.91 \pm 1.54^{\mathrm{b}}$ & $*$ \\
Finishing live weights & $48.072 \pm 1.99$ & $37.247 \pm 1.028$ & $38.470 \pm 0.880$ & $43.326 \pm 0.910$ & $\mathrm{~ns}$ \\
Hot carcass weight & $19.287 \pm 0.502$ & $18.215 \pm 0.416$ & $20.281 \pm 0.400$ & $19.859 \pm 0.407$ & $\mathrm{~ns}$ \\
Cold carcass weight & $18.735 \pm 0.503$ & $17.828 \pm 0.417$ & $19.871 \pm 0.400$ & $19.531 \pm 0.408$ & $\mathrm{~ns}$ \\
Tail weight & $0.663 \pm 0.208^{\mathrm{c}}$ & $0.552 \pm 0.172^{\mathrm{c}}$ & $4.542 \pm 0.165^{\mathrm{a}}$ & $1.690 \pm 0.168^{\mathrm{b}}$ & $* *$ \\
Starting tail length & $37.83 \pm 1.727^{\mathrm{c}}$ & $38.00 \pm 1.115^{\mathrm{c}}$ & $42.08 \pm 1.246^{\mathrm{c}}$ & $52.27 \pm 2.677^{\mathrm{a}}$ & $* *$ \\
Starting tail width & $16.67 \pm 2.213^{\mathrm{b}}$ & $11.75 \pm 0.579^{\mathrm{c}}$ & $25.92 \pm 1.730^{\mathrm{a}}$ & $18.36 \pm 1.545^{\mathrm{b}}$ & $* *$ \\
Finishing tail length & $48.13 \pm 1.811^{\mathrm{c}}$ & $50.29 \pm 1.983^{\mathrm{bc}}$ & $52.25 \pm 1.349^{\mathrm{b}}$ & $54.82 \pm 1.710^{\mathrm{ab}}$ & $*$ \\
Finishing tail width & $18.08 \pm 1.630^{\mathrm{b}}$ & $14.17 \pm 0.638^{\mathrm{c}}$ & $27.50 \pm 1.598^{\mathrm{a}}$ & $17.73 \pm 0.740^{\mathrm{b}}$ & $* *$ \\
\hline
\end{tabular}

a.b.c: The means indicated with different letters in the same row are significantly different; $* \mathrm{P}<0.05 ; * * \mathrm{P}<0.01$; ns: not significant

Evaluations in terms of tail fatty acid profile were made on tail fat samples of four breeds. When the presence, amount and breeds of the fatty acids found in tail fat were evaluated in terms of having these fatty acids, some differences were found. It has been found that the difference between breeds is very significant in terms of saturated fatty acids, monounsaturated and polyunsaturated fatty acids. There are significant differences between species in terms of fatty acid composition. Body fat saturation varies among animal species and according to breeds within the same species (Öztürkcan et al., 1996; Banskalieva et al., 2000).

According to the findings of the study, the content of saturated fatty acids in tail fat for the breeds of Artll, Çepni, Karayaka and Of, respectively; 52.08\%, 51.66\%, 42.67\% and Of 52.92\% ( $\mathrm{P}<0.05$ ), while the monounsaturated fatty acid contents were $33.25 \%$, 33.12\%, 33.07\%, and 32.34\% respectively. In terms of content of polyunsaturated fatty acids, it was determined as $0.76 \%, 1.20 \%, 0.64 \%$ and $0.87 \%$, respectively. The presence of fatty acids desired for health was determined as $46.94 \%$ in Artl, $51.03 \%$ in Çepni, $51.51 \%$ in Karayaka and $49.51 \%$ $(\mathrm{P}<0.05)$ in the breed of Of. In terms of polyunsaturated fatty acids in the composition of fatty acids, the highest rate was found in the Çepni breed and the lowest in the Karayaka breed (Table 2).

Studies reveal a relationship between people's eating habits and diseases. Today, fats are the most questioned when investigating the relationships between certain diseases and diets. In researches, especially the saturated or unsaturated structure of oils, cholesterol and essential fatty acid contents, and oxidative stability were emphasized (Karaca and Aytaç., 2007; Kayahan., 2009; Çakmakçı and Tahmas-Kahyaoğlu., 2012). The place and importance of animal products in a healthy and balanced diet is widely recognized. However, foods of animal origin, which are an important source of saturated fatty acids, are associated with the diseases of the modern lifestyle. The decrease in energy spent for physical activity in healthy living conditions makes it necessary to be more careful and selective in the diet. Today, especially in developed countries, people who want to maintain a healthy life take care of their nutrition for this reason. 
A-linolenic acid ratios, which are known to reduce the risk of cardiovascular disease and benefit brain health, for the breeds of Artl, Çepni, Karayaka and Of in tail fat were respectively; $0.035 \%, 0.148 \%, 0.056 \%, 0.080 \%$. The autherogenic index in tail fat was determined as $1.068 \%, 1.325 \%, 1.268 \%$ and $1.568 \%$ in Artl1, Çepni, Karayaka and Of breeds, respectively. It was determined that there was no difference between the groups in terms of monounsaturated fatty acids found in tail fat and recommended to be consumed in terms of health. However, considering the levels of polyunsaturated fatty acids, it was determined that the percentage of fatty acids in the tail fat of the Çepni breed was higher than the others, followed by Of, Artlı and Karayaka breeds respectively. When evaluated in terms of desired fatty acids values in tail fat (Costa et al., 2009) It was observed that the Karayaka breed was in the first place, followed by the Çepni, Of and Artlı breeds. In addition, when the breeds were compared in terms of mono and polyunsaturated fatty acids found in tail fat, it was found that there was no presence of some fatty acids among the breeds or that the animals in the experimental groups had this difference between animals in the same group or animals in all groups. In terms of tail fat saturated fatty acids, it was determined that the Karayaka race showed significantly lower values than the others among the breeds, but there was no difference between them. However, some fatty acids were found to be absent in some groups.

Table 2. Fatty acid compositions and fatty acid ratios in tail fat of lambs of different breeds (\%)

\begin{tabular}{|c|c|c|c|c|c|}
\hline Fatty acids & Artl1 & Çepni & Karayaka & Of & $\mathrm{P}$ \\
\hline Saturated fatty acids & $52.08 \pm 1.188^{a}$ & $51.66 \pm 1.093^{\mathrm{a}}$ & $42.67 \pm 1.562^{\mathrm{b}}$ & $52.92 \pm 1.219^{\mathrm{a}}$ & $* *$ \\
\hline C6:0 & $0.024 \pm 0.003$ & $0.020 \pm 0.001$ & $0.020 \pm 0.001$ & $0.025 \pm 0.003$ & ns \\
\hline C8:0 & $0.040 \pm 0.010^{\mathrm{a}}$ & $0.020 \pm 0.001^{\mathrm{b}}$ & $0.019 \pm 0.001^{\mathrm{b}}$ & $0.025 \pm 0.002^{\mathrm{ab}}$ & $*$ \\
\hline C10:0 & $0.298 \pm 0.024^{\mathrm{ab}}$ & $0.277 \pm 0.28^{b}$ & $0.288 \pm 0.008^{\mathrm{b}}$ & $0.362 \pm 0.021^{\mathrm{a}}$ & $*$ \\
\hline C11:0 & $0.052 \pm 0.006^{\mathrm{a}}$ & $0.016 \pm 0.003^{c}$ & $0.025 \pm 0.004^{\mathrm{b}}$ & $0.015 \pm 0.002^{\mathrm{c}}$ & ** \\
\hline C12:0 & $0.172 \pm 0.018^{\mathrm{c}}$ & $0.295 \pm 0.040^{\mathrm{b}}$ & $0.247 \pm 0.046^{\mathrm{bc}}$ & $0.498 \pm 0.050^{\mathrm{a}}$ & ** \\
\hline C13:0 & $0.084 \pm 0.006^{\mathrm{a}}$ & $0.048 \pm 0.003^{\mathrm{b}}$ & $0.055 \pm 0.008^{\mathrm{b}}$ & $0.050 \pm 0.004^{\mathrm{b}}$ & $* *$ \\
\hline C14:0 & $3.306 \pm 0.229^{c}$ & $4.496 \pm 0.319^{b}$ & $3.965 \pm 0.376^{\mathrm{bc}}$ & $6.170 \pm 0.196^{\mathrm{a}}$ & $* *$ \\
\hline C15:0 & $1.733 \pm 0.118^{\mathrm{a}}$ & $1.102 \pm 0.030^{\mathrm{b}}$ & $1.227 \pm 0.120^{\mathrm{b}}$ & $1.052 \pm 0.013^{\mathrm{b}}$ & $* *$ \\
\hline C16:0 & $21.816 \pm 0.911^{\mathrm{a}}$ & $25.289 \pm 0.699^{b}$ & $25.477 \pm 0.486^{\mathrm{b}}$ & $26.283 \pm 0.248^{b}$ & $* *$ \\
\hline C17:0 & $3.790 \pm 0.168^{\mathrm{a}}$ & $3.109 \pm 0.569^{b}$ & $3.143 \pm 0.225^{b}$ & $2.497 \pm 0.147^{c}$ & $*$ \\
\hline C18:0 & $11.235 \pm 0.774^{\mathrm{b}}$ & $16.714 \pm 0.569^{\mathrm{a}}$ & $17.505 \pm 0.775^{\mathrm{a}}$ & $15.800 \pm 1.506^{\mathrm{a}}$ & $* *$ \\
\hline C20:0 & $0.088 \pm 0.008$ & $0.096 \pm 0.007$ & $0.099 \pm 0.003$ & $0.110 \pm 0.010$ & ns \\
\hline C21:0 & $0.0278 \pm 0.005$ & $0.438 \pm 0.241$ & $0.030 \pm 0.006$ & $0.090 \pm 0.010$ & ns \\
\hline $\mathrm{C} 22: 0$ & $0.015 \pm 0.002$ & $0.016 \pm 0.002$ & $0.015 \pm 0.002$ & $0.015 \pm 0.003$ & ns \\
\hline Monounsaturated fatty acids & $33.25 \pm 0.676$ & $33.12 \pm 0.694$ & $33.07 \pm 1.553$ & $32.84 \pm 1.341$ & $\mathrm{~ns}$ \\
\hline C14:1 & $0.096 \pm 0.004^{\mathrm{b}}$ & $0.100 \pm 0.009^{b}$ & $0.082 \pm 0.006^{\mathrm{b}}$ & $0.192 \pm 0.034^{\mathrm{a}}$ & $* *$ \\
\hline C16:1 & $1.1610 .039^{\mathrm{b}}$ & $1.1390 .051^{\mathrm{b}}$ & $1.0740 .053^{\mathrm{b}}$ & $1.563 \pm 0.204^{\mathrm{a}}$ & * \\
\hline C18:1 & $3.532 \pm 0.929^{c}$ & $4.790 \pm 0.259^{\mathrm{a}}$ & $4.320 \pm 0.296^{\mathrm{ab}}$ & $3.890 \pm 0.176^{\mathrm{bc}}$ & $*$ \\
\hline C18:1n9c & $30.173 \pm 0.567$ & $27.014 \pm 0.505$ & $27.696 \pm 0.828$ & $27.133 \pm 1.212$ & ns \\
\hline $\mathrm{C} 20: 1$ & $0.130 \pm 0.019^{\mathrm{a}}$ & $0.072 \pm 0.005^{\mathrm{b}}$ & $0.077 \pm 0.007^{\mathrm{b}}$ & $0.057 \pm 0.006^{\mathrm{b}}$ & $* *$ \\
\hline Polyunsaturated fatty acids & $0.76 \pm 0.240$ & $1.20 \pm 0.428$ & $0.64 \pm 0.074$ & $0.87 \pm 0.102$ & ns \\
\hline C18:2 & $0.725 \pm 0.007$ & $1.051 \pm 0.347$ & $0.595 \pm 0.066$ & $0.793 \pm 0.083$ & ns \\
\hline C18:3 & $0.035 \pm 0.002$ & $0.148 \pm 0.079$ & $0.056 \pm 0.007$ & $0.080 \pm 0.019$ & ns \\
\hline C20:3 & nd & $0.015 \pm 0.005$ & nd & nd & \\
\hline C20:4 & nd & $0.035 \pm 0.004$ & nd & nd & \\
\hline PUFA / SFA & $0.0153 \pm 0.015$ & $0.0245 \pm 0.093$ & $0.0147 \pm 0.014$ & $0.0165 \pm 0.019$ & ns \\
\hline$\Sigma \mathrm{UFA} / \mathrm{SFA}$ & $0.8522 \pm 0.057^{\mathrm{a}}$ & $0.6705 \pm 0.035^{\mathrm{b}}$ & $0.6575 \pm 0.025^{\mathrm{b}}$ & $0.6413 \pm 0.039^{b}$ & $*$ \\
\hline Atherogenicity index $^{1}$ & $1.0677 \pm 0.090^{c}$ & $1.3247 \pm 0.087^{\mathrm{b}}$ & $1.2683 \pm 0.072^{\mathrm{bc}}$ & $1.5657 \pm 0.036^{\mathrm{a}}$ & $*$ \\
\hline Desired fatty acids ${ }^{2}$ & $46.94 \pm 1.813^{\mathrm{b}}$ & $51.03 \pm 0.891^{\mathrm{a}}$ & $51.51 \pm 1.017^{\mathrm{a}}$ & $49.51 \pm 0.489 \mathrm{a}^{\mathrm{b}}$ & $*$ \\
\hline (C18:0 + C18:1) / C16:0 & $1.9496 \pm 0.130$ & $1.8531 \pm 0.067$ & $1.8583 \pm 0.046$ & $1.7135 \pm 0.024$ & $\mathrm{~ns}$ \\
\hline Thrombogenic index ${ }^{3}$ & $2.071 \pm 0.161^{\mathrm{b}}$ & $2.670 \pm 0.163^{\mathrm{a}}$ & $2.753 \pm 0.099^{\mathrm{a}}$ & $2.853 \pm 0.192^{\mathrm{a}}$ & $*$ \\
\hline
\end{tabular}


${ }^{1}:\left[(\mathrm{C} 12: 0)+4 \mathrm{x}(\mathrm{C} 14: 0)+(\mathrm{C} 16: 0) / \Sigma \mathrm{UA} ;{ }^{2}:\right.$ [MUFA + PUFA + C18:0]; ${ }^{3}:[(\mathrm{C} 14: 0+\mathrm{C} 16: 0+\mathrm{C} 18: 0)] /[(0.5 \mathrm{MUFA}$ + 0.5 PUFAn-6 + 3PUFAn-3 + (n-3/ n/6)]; (Costa et al., 2009; Zhang et al., 2021).

a.b.c: The means indicated with different letters in the same row are significantly different; * $\mathrm{P}<0.05$; ** $\mathrm{P}<0.01$; ns: not significant; nd: not determined.

\section{Conclusion}

It has been determined that the fatty acid content has significant differences between breeds. As a result, it has been scientifically demonstrated that the fatty acid profile is an important source for the desired fatty acid content. However, more research is needed in this area. With the breeding and different fattening studies, more comprehensive information will be provided on the share of environmental and genotypic effects in the variations of both genotype differences and differences between genotypes in terms of tail fat fatty acids and body fat fatty acids.

\section{Acknowledgement}

This study was supported by the General Directorate of Agricultural Research and Policies (TAGEM) with the project number of TAGEM-17/ARGE/09.

\section{References}

Akçapınar, H., Özbeyaz, C., 1999. Hayvan yetiştiriciliği temel bilgileri. Kariyer Matbaacılık. pp. 28-9.

Akçapınar, H., 2000. Koyun yetiştiriciliği. 2. Baskı, İsmat Matbaacılık Ltd. Şti. Ankara. ISBN: 975-96978-1-5.

Aksoy, A., Yavuz, F., 2012. Analysis on the reasons for quitting sheep and goat rearing of farmers: a case of east Anatolia region. Anadolu Journal of Agricultural Sciences, 27(2): 76-79. https://doi.org/10.7161/anajas.2012.272.76

Banskalieva, V., Sahlu, T., Goetsch, A.L., 2000. Fatty acid composition of goats muscle and fat depots: a review. Small Ruminant Research, 37(3): 255-268. doi: 10.1016/s0921-4488(00)00128-0.

Behçet, R., Aydın, S., Çakmak, A., 2012. Using as fuel for a single cylindir diesel engine of biodiesels produced from vegetable and animal waste oils. Journal of The Institute of Science and Technology, 2(4), 55-62.

Canbolat, Ö., Karabulut, A., 2003. Using animal fats in ruminant nutrition. Journal of Food and Feed ScienceTechnology, 3: 50-59.

Costa, R.G., Batista, A.S.M., Azevedo, P.S., Queiroga RCRE., Madruga MS., Filho JTA., 2009. Lipid profile of lamb meat from different genotypes submitted to diets with different energy levels. Revista Brasileira de Zootecnia, 38(3):532-8. http://dx.doi.org/10.1590/S1516-35982009000300019

Çakmakçı, S., Tahmas-Kahyaoğlu, D., 2012. An overview of the effects of fatty acids on health and nutrition. Academic Food Journal, Akademik Gida, 10 (1): 103-113.

Demirel, G., Wood, J.D., Enser, M., 2004. Conjugated linoleic acid content of the lamb muscle and liver fed $\begin{array}{llllll}\text { different } & \text { supplements. } & \text { Small } & \text { Ruminant }\end{array}$ https://doi.org/10.1016/j.smallrumres.2003.07.006

Donna, M.R.W., Hemken, R.W., Jackson, J.A., 2002. Should you be feeding fat to yourj dairy cows. University of Kentucky Concise discussion with helpful tips for managing fat feeding on the farm. Available from URL: http://www2.ca.uky.edu/agcomm/pubs/asc/asc134/asc134.pdf (Accessed: 20.10.2020).

Forrest, J.C., Aberle, E.D., Hedrick, H.B., Judge, M.D., Merkel, R.A., 1975. Principles of Meat Science. W.H. Freeman and Company. San Francisco, ISBN: 0716707438 pp. 417.

Kashan, N.E., Manafi Azar, J., Afzalzadeh, G.H., Salehi, A., 2005. Growth performance and carcass quality of fattening lambs from fat-tailed and tailed sheep breeds. Small Ruminant Research, 60(3): 267-71. https://doi.org/10.1016/j.smallrumres.2005.01.001

Karaosmanoğlu, F., 2002. Türkiye için çevre dostu-yenilenebilir bir yakıt adayı: Biyomotorin. Ekojenerasyon Dünyası-Kojenerasyon Dergisi, ICCI 2002 Özel sayısı, İstanbul, 10: 50-56.

Karaca, E., Aytaç, S., 2007. The factors affecting on fatty acid composition of oil crops. Anadolu Journal of Agricultural Science, 22(1): 123- 131.

Kayahan, M., 2009. Sağlıklı beslenme açısından trans yağ asitleri. II. Geleneksel Gıdalar Sempozyumu. 27-29 Mayis 2009, Van.

Kaymakçı, M., 2006. İleri koyun yetiştiriciliği, İzmir ili damızlık koyun-keçi yetiştiricileri birliği, Yayın No:1 Bornova, İzmir.

Lunn, J, Theobald, H.E., 2006. The health effects of dietary unsaturated fatty acids. Nutrition Bulletin, 31: 178-224. 
NRC., 2007. Nutrient Requirements of Small Ruminants: Sheep, Goats, Cervids, and New World Camelids. 362P, National Academy Press, Washington, DC.

Öztürkcan, O., Demir, E., Görgülü, M., 1996. Çiftlik hayvanlarında yağlanma. Çukurova Üniversitesi Ziraat Fakültesi, Genel Yayın No 136.

Öztürk, Y., Odabaşıŏlu, F., 2011. The investigation of yield and morphological characteristics of Hamdani sheep in Van area; II. growth, survival rate, fattening performance, slaughter and carcass characteristics of lambs. The Journal of The Faculty of Veterinary Medicine University of Yuzuncu Y1l, 22(2): 81-87.

Pehlivanoğlu, H., Demirci, M., Toker, O. S., Konar, N., Karasu, S., Sagdic, O., 2018. Oleogels, a promising structured oil for decreasing saturated fatty acid concentrations: Production and food-based applications. Critical Reviews in Food Science and Nutrition, 58(8):1330-1341. https://doi.org/10.1080/10408398.2016.1256866

Raes, K., De Smet, S., Demeyer, D., 2004. Effect of dietary fatty acids on incorporation of long chain polyunsaturated fatty acids and conjugated linoleic acid in lamb, beef and pork meat: A review. Animal Feed Science and Technology, 113(1-4): 199-221. https://doi.org/10.1016/j.anifeedsci.2003.09.001

Tekin, M.E., Akçapınar, H., 1994. Türk Merinosu ve Lincoln x Türk Merinosu $\left(\mathrm{F}_{1}\right)$ melezi kuzuların büyüme, besi ve karkas özelliklerinin karşılaştırılması. I. büyüme özellikleri. Doğa Türk Veterinerlik ve Hayvancılık Dergisi, 4:181-187.

Teke, B., Uğurlu, M., Akdağ, F., Arslan, S., Ekiz, B., 2018. Entansif koşullarda beslenen Herik kuzularında karkas kompozisyonun belirlenmesi. Journal of Faculty of Veterinary Medicine, Erciyes University, 15(1): 1-5.

Utlu, Z., 2007. Evaluation of biodiesel obtained from waste cooking oil. Energy Sources, Part A: Recovery, Utilization, and Environmental Effects, 29:1295-1304. https://doi.org/10.1080/00908310500434564

Ünal, K., Karakaya, M., 2017. The effect of clove and cinnamon on some physicochemical properties of sucuk produced by different animal fat types. Journal of Tekirdag Agricultural Faculty, 14(3), 55-65.

Üstün, S., 2006. Biodiesel production from animal fats. PhD Thesis. Selçuk University Institute of Science and Technology.

Wood, J.D., Richardson, R.I., Nute, G.R., Fisher, A.V., Campo, M.M., Kasapidou, E., Sheard, P.R., Enser, M., 2003. Effects of fatty acids on meat quality: a review. Meat Science, 66(1): 21-32. https://doi.org/10.1016/S0309-1740(03)00022-6

Zhang, Q., Que, M., Li, W., Gao, S., Tan, X., Bu, D., 2021. Gangba sheep in the Tibetan plateau: Validating their unique meat quality and grazing factor analysis. Journal of Environmental Sciences, 101(3): 117-122. https://doi.org/10.1016/j.jes.2020.06.024 